\title{
Generasi milenial dan Pancasila
}

\section{Bambang Arianto}

Institute for Digital Democracy dan STISIP Banten Raya Pandeglang

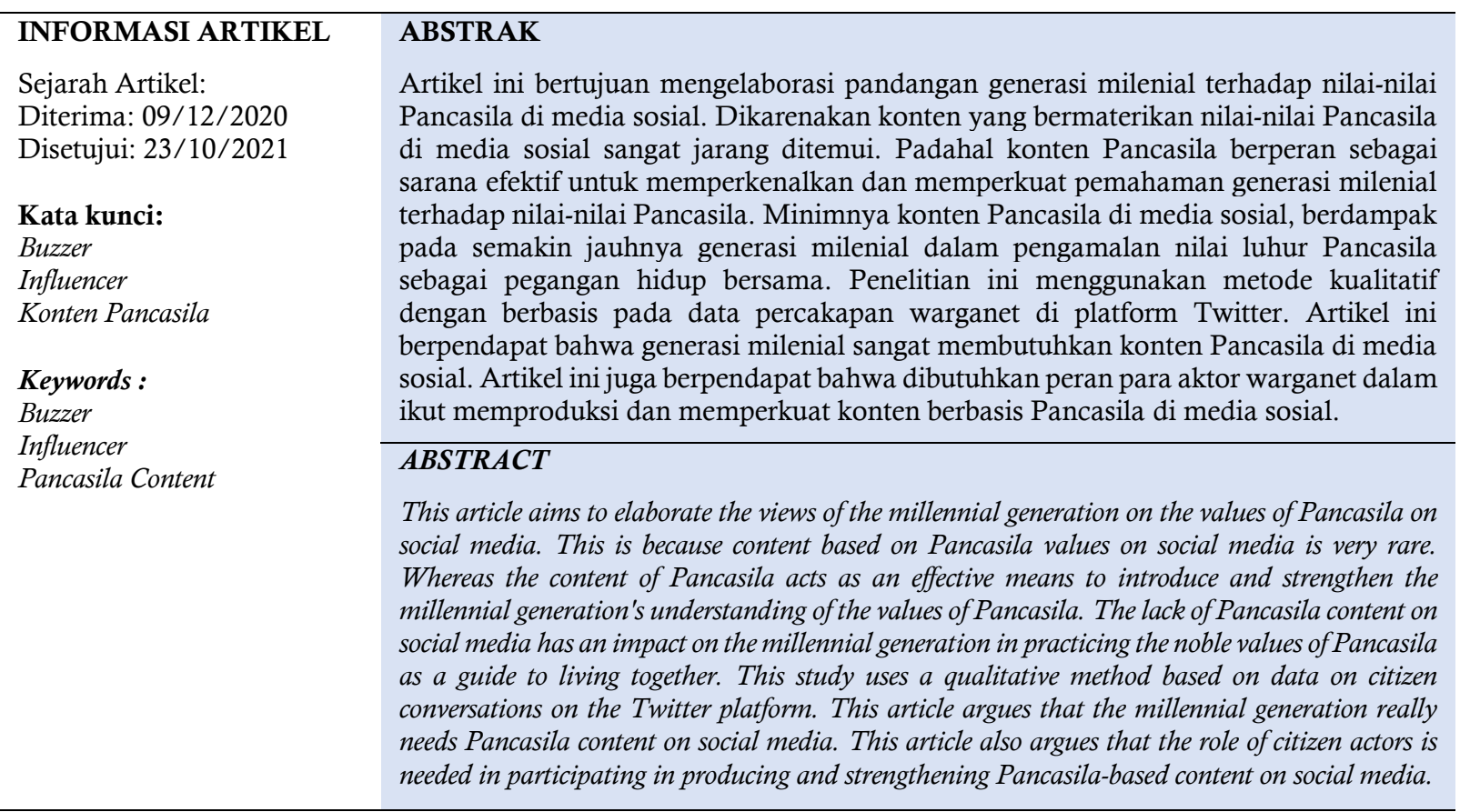

\section{Pendahuluan}

Beberapa sindikat penyebar ujaran kebencian di media sosial telah banyak terungkap oleh Direktorat Tindak Pidana Siber Bareskrim Polri sebagai bukti bahwa agensi ujaran kebencian benar adanya (katadata.com, 2017). Dengan demikian, dunia maya terutama media sosial tidak bisa lepas dari berbagai informasi hoaks hingga ujaran kebencian. Artinya, media sosial seringkali dimanfaatkan oleh pihak-pihak tertentu untuk menyebarkan ujaran kebencian, hasutan dan propaganda dengan sasaran generasi milenial. Hal itu dapat di lacak dari banyaknya konten yang beredar ternyata bermaterikan paham-paham intoleransi dan radikalisme yang jauh dari semangat Pancasila. Termasuk meningkatnya peredaran konten yang mengkampanyekan ideologi alternatif yang tentunya berseberangan dengan nilai-nilai Pancasila.

Ironisnya lagi, terjadi krisis konten kreatif yang membawa nilai-nilai Pancasila seperti konten keberagamaan dan kebangsaan di media sosial. Sehingga, media sosial semakin banal oleh peredaran konten negatif, hoaks dan ujaran kebencian. Alhasil, bila terus dibiarkan, hal ini dapat membuat kekhawatiran akan mencuatnya beragam varian propaganda digital yang berujung adu domba. Sebab, seringkali konten tersebut membawa wacana seksional seperti ujaran kebencian yang sektarianisme dan hoaks yang bisa mengancam keutuhan bangsa serta memecah belah rakyat Indonesia. Apalagi, hal itu diperparah, dengan masih sedikitnya warganet yang mereproduksi konten kreatif berbasis Pancasila.

Oleh sebab itu, untuk meredam persebaran konten intoleransi dan radikal yang muncul di media sosial, pemerintah tidak cukup dengan hanya memblokir situs atau menindak para 
penyebarnya berdasarkan Undang-undang Informasi dan Transaksi Elektronik (UU ITE). Artinya di era digital diperlukan langkah taktis yang bisa meredam persebaran konten intoleransi dan radikalisme, salah satunya dengan memperkuat persebaran konten kreatif dengan membawa nilainilai Pancasila di media sosial. Persebaran konten ini bisa dilakukan oleh akun-akun resmi pemerintah serta peran aktor warganet yang peduli dengan nilai-nilai kebangsaan dan Pancasila. Dengan langkah ini setidaknya dapat mendorong para warganet (netizen) lainnya untuk ikut bersama-sama menyebarkan dan menawarkan informasi alternatif berupa konten-konten yang bermaterikan nilainilai kebangsaan, keberagaman dan Pancasila.

Dikatakan demikian karena menjamurmya konten intoleransi dan radikalisme harus segera diimbangi dengan membanjirnya informasi alternatif yang membawa nilai-nilai Pancasila. Melalui konten alternatif yang berisi muatan ideologis kebangsaan dapat menjadi pembanding berbagai informasi yang bermaterikan intoleransi dan radikalisme. Konten-konten kreatif kebangsaan itu bisa berbentuk meme, video hingga beragam pemberitaan positif perihal upaya mempertegas nilai-nilai kebangsaan dan Pancasila. Sebab yang dibutuhkan saat ini bukan sebatas literasi anti hoaks semata, akan tetapi yang lebih penting adalah bagaimana para warganet bisa mendapatkan konten kreatif seputar kebangsaan dan Pancasila di media sosial.

Artinya diperlukan upaya mereproduksi konten kreatif berbasis Pancasila di media sosial dari semua simpul masyarakat sipil termasuk warganet. Konten tersebut dapat dimodifikasi secara kreatif dengan memberikan panduan dan edukasi praktis bagi warganet untuk dapat berfikir kritis dalam mengkampanyekan semangat Pancasila. Dengan adanya sinergisitas ini diharapkan dapat mengatasi krisis konten kreatif Pancasila. Sekaligus bisa menyelamatkan generasi milenial dari paparan konten negatif yang berpotensi memecah belah keutuhan bangsa. Sebab dampak dari penyebarluasan berita dan pesan yang mengandung konten bermuatan suku, agama, ras dan antar golongan (SARA) tentu akan dapat memecah belah persatuan bangsa (Emillia, 2020).

Lebih lanjut, untuk mempertegas upaya membumikan Pancasila dalam ranah media sosial, peran aktor warganet yang setia kepada nilai-nilai Pancasila mutlak diperlukan. Aktor warganet seperti influencer dan buzzer media sosial dapat didorong untuk turut aktif berjuang menyebarluaskan konten kreatif kebangsaan berwatak Pancasila di media sosialnya masing-masing. Sebab, untuk bisa membumikan Pancasila pada generasi milenial, tentu diharapkan konten-konten berbasis Pancasila yang dapat menguasai media sosial. Dikarenakan media sosial hingga saat ini telah berperan dalam pembentukan politik kontemporer yang demokratis. Seperti forum diskusi digital yang bisa memberi kebebasan untuk mengekspresikan dan memberdayakan potensi diri (Loader \& Mercea, 2011).

Dengan pemanfaatan media sosial diharapkan nilai-nilai Pancasila kembali membumi dalam nalar para warganet (netizen) sebagai ideologi sekaligus pandangan hidup bersama. Pentingnya upaya membumikan konten Pancasila di media sosial, lebih disebabkan peran media sosial yang telah terbukti menjadi pengerak utama dalam menghasilkan beragam opini, wacana dan kesadaran tentang kebijakan yang transformatif. Kondisi ini dapat berpengaruh pada pembentukan sistem informasi dan pengetahuan warganet yang kemudian bisa menjadi otoritas tertinggi dalam opini publik. Dengan kata lain, opini publik bisa muncul dari berbagai serpihan konten-konten Pancasila yang bertebaran di media sosial.

Lebih lanjut, menitikberatkan media sosial sebagai saluran untuk menyebarkan konten kreatif berbasis Pancasila, dikarenakan media baru ini dikenal sebagai medium partisipator. Selain informatif dan interaktif, medium ini memiliki watak partisipatoris karena dirancang untuk memungkinkan setiap individu untuk menjadi pribadi yang dapat terlibat membentuk masyarakat dalam komunitasnya (Bowman \& Willis, 2003). Meski begitu tetap diperlukan inovasi lanjutan dalam pengembangan media pembelajaran seperti penggunaan media sosial Youtube dalam perkuliahan pendidikan kewarganegaraan di perguruan tinggi (Muharam \& Prasetyo, 2021).

Dengan melihat kondisi tersebut, tugas berat para warganet dan pegiat komunitas literasi digital yakni harus berupaya menghilangkan berbagai konten hoaks dan ujaran kebencian di media sosial. Artinya, untuk menghilangkan konten negatif diperlukan lebih banyak konten kreatif yang diharapkan dapat membumikan Pancasila dalam nalar generasi milenial. Sebab karakter generasi milenial lebih menyukai model kampanye kreatif yang mengedepankan konten-konten kreatif (Arianto, 2015a). Dengan demikian, kampanye untuk mereproduksi konten Pancasila menjadi hal 
yang penting dan harus segera ditindaklanjuti agar nilai-nilai Pancasila bisa menjadi rujukan bagi setiap postingan generasi milenial di media sosial. Adapun materi konten Pancasila bisa berupa nilainilai yang menjabarkan sikap toleransi, saling menghargai, gotong royong hingga semangat mengedepankan musyarawah antar warga masyarakat. Dengan turut memproduksi konten kreatif Pancasila dengan teknik dan karakteristik masing-masing, sama artinya membentengi warganet dari berbagai upaya pecah belah serta serangan ideologis dari luar Pancasila.

Beberapa studi telah menjelaskan pentingnya membumikan Pancasila kepada para generasi muda penerus bangsa (Wulandari \& Dewi, 2021). Salah satu langkahnya dengan pemanfaatan media sosial. Sebab media sosial memberikan peluang besar bagi generasi milenial untuk mengimplementasikan nilai nilai Pancasila (Effendi \& Dewi, 2021). Selain itu beberapa studi telah mengelaborasi pandangan generasi muda dalam memahami Pancasila di era milenial (Wulandari, 2021). Termasuk upaya menerapkan nilai-nilai Pancasila bagi peserta didik di era globalisasi melalui momentum hari besar nasional (Asmaroini, 2016). Dengan begitu, generasi muda terutama milenial senantiasi dapat memahami nilai-nilai yang terkandung dalam Pancasila serta dapat menjadikannya sebagai acuan dalam kehidupan keseharian (Suwandi \& Dewi, 2021).

Lebih lanjut, ada pula yang berupaya membangun perkampungan Pancasila yang menerapkan nilai-nilai Pancasila sebagai upaya pembentukan karakter bangsa. Meski demikian, dalam implementasinya penerapan nilai-nilai Pancasila masih belum banyak mendapat dukungan dari masyarakat termasuk kesadaran akan perilaku yang mencerminkan nilai-nilai Pancasila sebagai penguatan karakter bangsa. Bahkan penelitian tersebut mendorong adanya dukungan dari berbagai pihak yang berwenang di dalamnya untuk lebih menerapkan nilai-nilai Pancasila dalam semua sendi kehidupan (Damanhuri, 2016). Selain itu, juga telah banyak studi terdahulu yang mengelaborasi upaya membumikan Pancasila dalam nalar generasi muda (Handitya, 2019; Safitri \& Dewi, 2021; Suwandi \& Dewi, 2021; Wulandari \& Dewi, 2021; Effendi, \& Dewi, 2021).

Akan tetapi, belum banyak yang mengelaborasi perihal generasi milenial dan Pancasila secara khusus. Sehingga perbedaan penelitian ini terletak pada pandangan generasi milenial terhadap Pancasila di media sosial serta upaya mencari langkah alternatif dalam membumikan Pancasila di media sosial. Dengan berbasis data percakapan di media sosial, langkah taktis yang diambil yakni memproduksi konten Pancasila dan bersinergi antar aktor warganet untuk internalisasi nilai-nilai Pancasila. Sehingga dengan demikian, penelitian ini sejatinya ingin mengetahui bagaimana pandangan generasi milenial terhadap Pancasila di media sosial. Implikasi dalam penelitian ini seputar pandangan generasi milenial terhadap Pancasila berdasarkan data-data percakapan warganet di media sosial.

\section{Metode}

Penelitian ini menggunakan pendekatan metode kualititatif yang berbasis percakapan media sosial Twitter melalui data Social Network Analisys (SNA) yang berasal dari Drone Emprit Academic (DEA) Universitas Islam Indonesia (Fahmi, 2019). Aplikasi Drone Emprit Academic merupakan suatu sistem data besar (big data) yang dapat melakukan analisis jejaring sosial dari percakapan media sosial secara semi real time dan detail. Dengan berbasis teknologi big data yang menggunakan artifial intelligence (AI) dan natural learning process (NLP), Drone Emprit Academic dapat menyajikan peta SNA tentang fenomena sosial yang terjadi di media sosial, mulai dari mengenal awal mula percakapan, siapa yang menginisiasi, hingga kelompok-kelompok mana saja yang ikut membicarakannya (Adji et al., 2019; Arianto, 2020d). Lebih lanjut data ini diambil dari percakapan warganet yang menggunakan kata kunci (keyword) Pancasila dan generasi milenial dari tanggal 6 Desember 2019 hingga 6 Januari 2020 dengan memfokuskan pada percakapan media sosial di platform Twitter. Selain itu, untuk memperkuat penelitian ini, kajian ini didukung oleh berbagai literatur baik dari jurnal ilmiah, buku hingga media online yang sesuai dengan topik penelitian. 


\section{Hasil dan Pembahasan}

\section{Mengenal Masyarakat Digital}

Generasi milenial berasal dari millennials diciptakan oleh dua pakar sejarah dan penulis Amerika, William Strauss dan Neil Howe dalam bukunya Millennial Generation atau generasi Y yang seringkali disebut generation me atau echo boomers. Secara harfiah memang tidak ada demografi khusus dalam menentukan kelompok generasi yang satu ini. Tetapi para pakar menggolongkannya berdasarkan tahun awal dan akhir. Penggolongan generasi Y terbentuk bagi yang lahir pada 19801990, atau pada awal 2000, dan seterusnya (Kominfo.go.id, 2016).

Meski begitu, generasi yang lahir antara tahun 1980 dan 1999 memiliki karakter dan watak berfikir yang berbeda. Dikatakan demikian, karena generasi milenial bisa diartikan sebagai generasi reinkarnasi "kaum muda baru" yang dipercaya bisa turut mengubah arah bangsa kedepan. Sebab generasi ini tampak lebih mengedepankan sikap kritis, kreatif, dan objektif dalam mengelaborasi suatu permasalahan. Kaum muda baru yang tampak lebih rasional, kritis dan mengedepankan obyektifitas termasuk dalam pemilihan konten di media sosial. Artinya, generasi milenial merupakan generasi yang memiliki semangat kreativitas dengan ketergantungan yang tinggi terhadap teknologi informasi.

Lebih lanjut, generasi milenial yang mayoritas merupakan warganet tentu memiliki beberapa klasifikasi, seiring perkembangan masyarakat digital. Klasifikasi tersebut dibagi berdasarkan tingkat keaktifan di media sosial yaitu; follower, buzzer dan influencer. Dalam hal ini bisa dikatakan sebagai follower yaitu merupakan akun media sosial yang secara khusus menjadi pengikut. Sedangkan akun buzzer merupakan akun media sosial yang setiap saat bertugas untuk mengkampanyekan dan mendengungkan suatu pesan atau konten kepada warganet dengan tujuan memperkuat pesan atau konten tersebut. Terakhir, akun influencer yaitu akun media sosial yang memiliki pengaruh kuat sehingga dapat mendorong para pengikutnya untuk dapat berbuat sesuai nalar atau kehendaknya.

Lebih lanjut, para aktor warganet ini memiliki peran dan fungsi masing-masing. 1) Follower; sebagai penerima akhir pesan dari buzzer dan influencer serta bertugas menyebarluaskan konten yang berasal buzzer dan influencer. 2) Buzzer, membentuk dan memperkuat opini publik dalam ranah media sosial dengan menempati trending topik Twitter dan membangun isu publik yang berasal dari investigasi individu maupun berasal dari influencer yang memiliki gagasan sama. Selain itu akun buzzer bertugas menyebarluaskan suatu pesan dan konten semua platform media sosial sehingga semakin kuat dalam nalar warganet. Terakhir akun influencer bertugas membangun ide awal bagi pembentukan opini publik yang kemudian dapat diteruskan oleh akun buzzer dan follower dengan retweet, repost atau reshare. Selain itu influencer bertugas membangun opini melalui proses investigasi untuk membantu para follower dan buzzer memahami suatu isu atau opini yang lagi berkembang (Arianto, 2020b).

Dengan demikian, peran aktor warganet sangat mempengaruhi pola pikir generasi milenial kedepan. Artinya generasi milenial akan sangat dipengaruhi oleh seberapa besar generasi milenial mencerma sebuah informasi. Bila informasi itu salah, maka secara otomatis informasi yang diterima akan menjadi pegangan bagi generasi milenial. Dengan kata lain, bila para generasi senior salah dalam memberikan konten kepada generasi penerusnya, maka secara tidak langsung akan memperbesar kemungkinan terpapar dengan konten negatif. Bahkan, bisa jadi generasi milenial dapat terpapar konten radikal, ketika generasi senior tidak mampu memberikan konten-konten yang berbasis Pancasila. Apalagi dekade terakhir terjadi krisis konten Pancasila yang diakibatkan menurunnya reproduksi konten Pancasila pasca era reformasi 1998. Sehingga generasi milenial sangat sedikit untuk mengenal konten-konten yang membawa misi kebangsaan dan keberagamaan yang terkandung dalam Pancasila.

Hal itu tanpa alasan, sebab kelahiran generasi milenial bertepatan dengan terjadinya kekosongan ideologi yang melanda seluruh bangsa ini terutama gerakan mahasiswa paska reformasi 1998. Sehingga terjadi defisit pemahaman dan pemeliharaan nilai-nilai Pancasila. Apalagi saat itu Badan Pembina Pendidikan Pelaksanaan Pedoman Penghayatan dan Pengamalan Pancasila (BP7) dan Pedoman Penghayatan dan Pengamalan Pancasila (P4) dibubarkan karena tidak lagi memiliki legitimasi dimata publik. Ketiadaan dari program ini cukup mempengaruhi pengenalan konten Pancasila dihadapan publik. Tentulah penurunan konten Pancasila secara drastis ini membuat publik merasa kehilangan pegangan serta landasan kokoh dalam bernegara dan berbangsa. Hal itu yang 
kemudian membuat terjadi gelombang eksodus beragam ideologi yang anti Pancasila. Artinya, berawal dari sinilah kemudian banyak bermunculan ideologi transnasional yang terus mempengaruhi publik hingga saat ini.

Hal itu diperparah lagi dengan tidak ada satu pun institusi yang secara fokus bertanggung jawab untuk tetap merawat nilai-nilai Pancasila. Akibatnya defisit nilai-nilai Pancasila ditengah masyarakat semakin nyata, seperti menurunnya nilai-nilai toleransi ditengah masyarakat. Bila mengutip data dari Laboratorium Pengukuran Ketahanan Nasional (Labkurtannas) dari Lembaga Ketahanan Nasional menyebutkan bahwa tengah terjadi penurunan poin dalam indeks ketahanan nasional dari 2,31 pada tahun 2010 menjadi 2,06 pada tahun 2016. Indeks tersebut meliputi variabel toleransi, kederajatan dalam hukum, kesamaan hak kehidupan sosial dan persatuan bangsa.

Gambaran lain diperlihatkan oleh hasil survei nilai-nilai kebangsaan yang dilakukan BPS. Berdasarkan survei tersebut, dari 100 orang di Indonesia terdapat 18 orang tidak mengenal judul lagu kebangsaan Republik Indonesia, kemudian ada 24 orang dari 100 orang di Indonesia yang justru tidak hafal sila-sila Pancasila. Selain itu terdapat 53 persen orang Indonesia tidak hafal lirik lagu kebangsaan, serta ada 55 persen orang Indonesia jarang dan bahkan tidak pernah ikut kerja bakti di lingkungannya. Identifikasi tersebut mengonfirmasi bahwa tantangan untuk merawat Pancasila di era digital tentu semakin berat. Artinya, Pancasila belum sepenuhnya dapat dihayati dan diamalkan oleh masyarakat (Wulandari, 2021). Padahal Pancasila sebagai pandangan hidup bangsa sudah seharusnya diamalkan sebagai pedoman dalam bersikap dan berperilaku dalam kehidupan keseharian termasuk di media sosial (Emillia, 2020).

Oleh sebab itu, untuk kembali mempertegas pemahaman nilai-nilai Pancasila ditengah masyarakat diperlukan komitmen bersama termasuk semua simpul masyarakat sipil yang berjejaring dengan generasi milenial seperti perguruan tinggi dan sekolah. Sebab, pemerintah tentulah tidak bisa berjalan sendiri tanpa dukungan dari masyarakat dan mahasiswa. Dengan cara itu, peran perguruan tinggi harus dapat merangkul semua simpul gerakan mahasiswa termasuk komunitas mahasiswa untuk bersama-sama merawat Pancasila sesuai konteks kekinian. Dengan begitu pegiat komunitas inilah yang diharapkan bisa lebih mengerti cara membangun berbagai program untuk membumikan Pancasila dengan model kampanye kekinian.

Dengan kata lain, proses merawat Pancasila harus dapat beradaptasi dengan perkembangan teknologi informasi yang merupakan bagian dari era revolusi industri 4.0. Tujuannya untuk bisa menarik atensi para warganet yang notabene adalah para generasi milenial dan generasi $Z$. Sehingga dari simpul komunitas itu dapat terlahir beragam program-program kreatif dan inovatif serta jauh dari kesan indoktrinisasi. Selain itu langkah lain yang bisa digunakan yakni dengan mendekati generasi milenial melalui pemanfaatan media sosial sebagai sarana membumikan nilai-nilai Pancasila. Tidak lupa, pihak kampus harus mendorong agar elemen gerakan mahasiswa dapat menyediakan berbagai informasi yang berguna bagi publik terutama seputar Pancasila dan ideologi kebangsaan.

Informasi ini sejatinya dapat menjadi suplemen bagi para mahasiswa dalam upaya membumikan Pancasila dan nilai-nilai kebangsaan. Dengan begitu hal ini akan semakin menegaskan bahwa elemen gerakan mahasiswa dapat berperan sebagai pengawas sekaligus suplemen terhadap jalannya politik pembinaan ideologi bangsa dan Pancasila dari dalam kampus. Sehingga dengan begitu, kampus akan tetap menjadi garda terdepan yang bisa menghasilkan beragam informasi dan suplemen bagi penghayatan pendidikan Pancasila. Meski begitu dalam konteks perguruan tinggi upaya membumikan Pancasila kepada generasi milenial, tetap membutuhkan adaptasi teknologi informasi dari para tenaga pengajar (Susanto, 2018). Sebab, sudah saatnya para pendidik bisa beradaptasi dengan dunia digital sehingga dapat ikut memproduksi konten-konten berbasis Pancasila di media sosial.

\section{Konten Pancasila}

Konten yang baik tentulah konten kreatif yang dapat menarik perhatian para warganet. Oleh sebab itu dalam media sosial dikenal beberapa jenis konten kreatif yang seringkali digunakan dalam mengedukasi warganet diantaranya; (1) Teks, merupakan konten yang masih banyak diperlukan dalam media sosial dengan tujuan agar bisa dibaca para warganet. Sebab tidak semua warganet 
menyukai melihat visual seperti video atau foto. Tetapi banyak pula warganet yang lebih menyukai membaca dari cuitan berupa teks di Twitter atau media sosial lainnya (2). Meme atau dikenal meme comics merupakan sebentuk tiruan dari berbagai gambar yang telah dikenal akrab (familiar) oleh warganet. Artinya, meme comics merupakan hasil montase atau rekayasa visual dari sejumlah gambar yang telah populer. Ketiga, video menjadi salah satu konten yang paling digemari oleh warganet. Bahkan, konten jenis ini menempati urutan pertama dari jenis konten yang memiliki tingkat interaksi paling tinggi di media sosial (Arianto, 2020b).

Dengan begitu, tugas berat para warganet dan pegiat komunitas literasi digital saat ini adalah berupaya menghilangkan berbagai konten yang tidak mencerminkan nilai-nilai Pancasila. Salah satu alternatif yang bisa dilakukan adalah dengan memperbanyak konten-konten berbasis Pancasila di media sosial. Dengan demikian, saat ini sangat dibutuhkan beragam konten positif dan kreatif yang membawa nilai-nilai Pancasila di media sosial untuk menandingi berbagai bentuk konten yang bermuatan ujaran kebencian dan anti Pancasila. Dengan kata lain, semua pegiat komunitas literasi digital termasuk Kementerian Komunikasi dan Informatika harus dapat membangun jejaring bersama literasi digital untuk memproduksi konten yang membawa nilai-nilai Pancasila. Artinya kampanye reproduksi konten Pancasila menjadi hal yang penting untuk segera ditindaklanjuti agar nilai-nilai Pancasila bisa kembali menjadi nafas bagi setiap postingan generasi milenial di media sosial.

Lebih lanjut, konten Pancasila dengan kemasan kekinian, seperti video, meme hingga aplikasi game dipercaya akan lebih mudah dipahami oleh generasi milenial. Sebab model atau kemasan konten kreatif sangat mempengaruhi ketertarikan generasi milenial untuk semakin mengenalnya. Dengan demikian, upaya membumikan nilai-nilai Pancasila dalam nalar warganet tentu diperlukan konten kreatif yang dapat membuat warganet tercerahkan akan informasi terkait Pancasila. Hal itu dapat dilacak dari salah satu konten berbasis Pancasila yang sangat disukai oleh para warganet. Berikut contoh salah satu konten dari gambar (image) yang banyak mendapatkan interaksi dan menjadi bahan diskusi para warganet di Twitter.

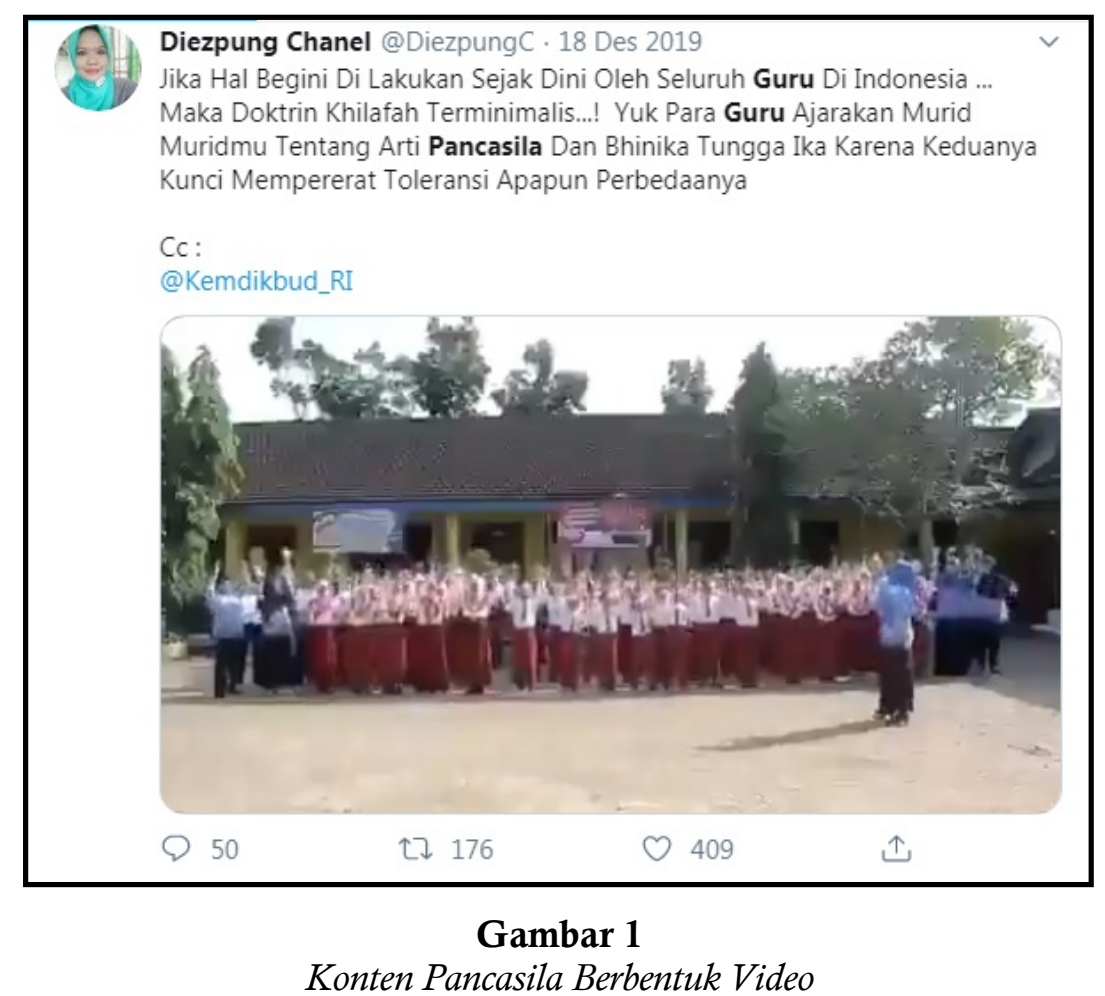

Sumber Data : Akun Twitter @DiezpungC 18 Desember 2019

Gambar tersebut menjelaskan salah satu konten Pancasila yang berbentuk video yang banyak mendapat perhatian warganet. Unggahan ini disertai frasa yang menyebutkan "Jika hal begini di 
lakukan sejak dini oleh seluruh Guru di Indonesia, maka doktrin khilafah terminimalis!. Yuk para Guru ajarkan murid-muridmu tentang arti Pancasila dan Bhinneka Tunggal Ika karena keduanya kunci mempererat toleransi apapun perbedaanya". Dari unggahan tersebut diketahui ada 176 retweet, 409 yang memberikan suka (like) serta ada 50 yang ikut memberikan komentar. Dengan demikian bisa dikatakan konten Pancasila sangat banyak disukai oleh warganet yang notabene adalah generasi milenial. Artinya, konten-konten Pancasila bila dikemas dengan kreatif tentu akan banyak mendapat perhatian warganet. Dengan demikian ikut serta dalam memproduksi konten kreatif Pancasila dengan teknik dan frase masing-masing, sama artinya menyelamatkan para warganet dari berbagai upaya pecah belah serta serangan ideologis.

\section{Pandangan Generasi Milenial Terhadap Pancasila di Twitter}

Dalam data ini ditunjukan peta persebaran cluster percakapan perihal Pancasila di kalangan generasi milenial dan generasi $\mathrm{Z}$ di media sosial Twitter. Tampak para influencer cukup banyak mendapat respon dari para warganet dalam percakapan ini. Dalam analisis persebaran percakapan yang berdasarkan data Social Network Analysis (SNA) Drone Emprit Academic, diketahui terdapat 7245 percakapan dengan tema "Pancasila di kalangan Generasi Milenial dan Generasi Z"

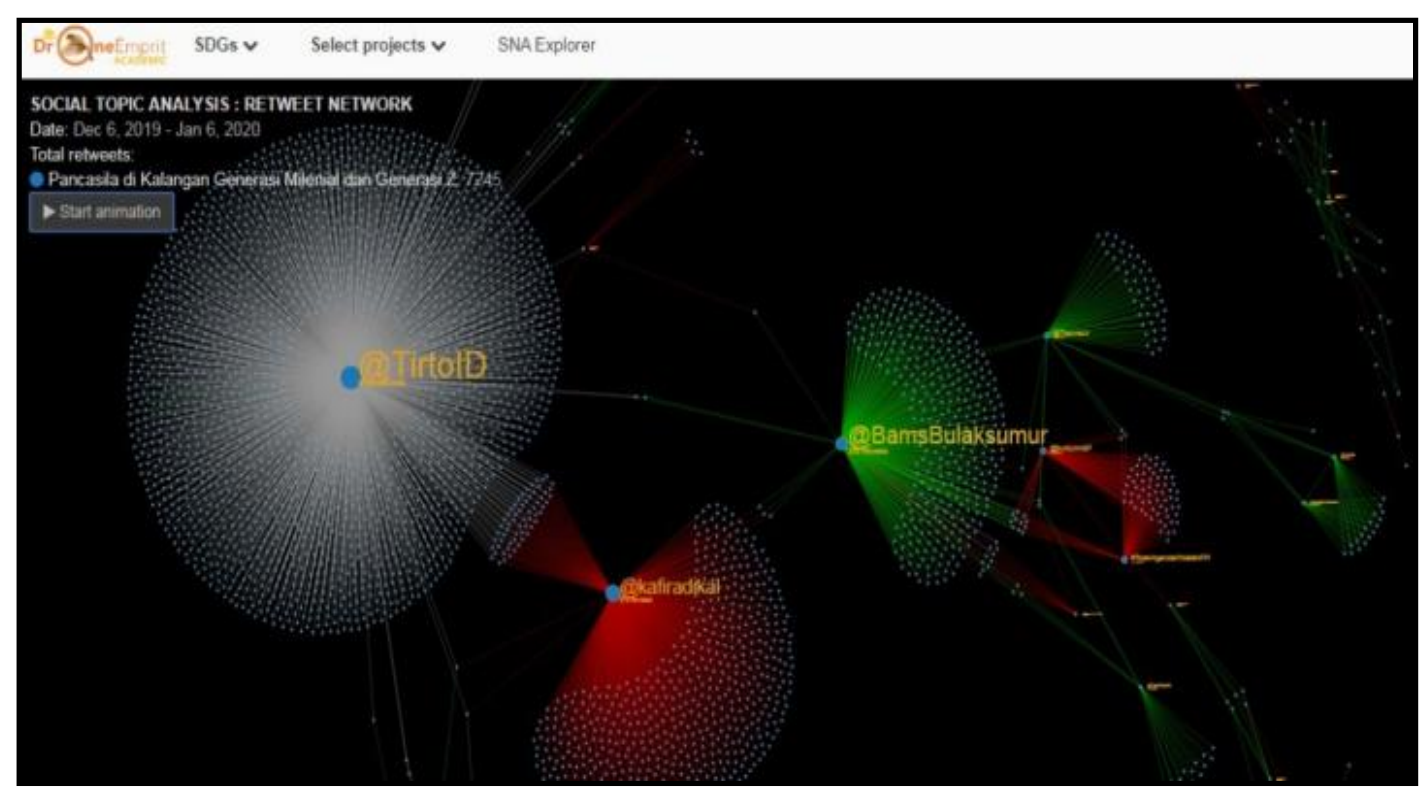

Gambar 2

Social Network Analysis di Twitter

Sumber Data : Drone Emprit Academic (2020)

Dalam percakapan mengenai Pancasila dan generasi milenial, interaksi dalam media sosial sangat interaktif. Menurut data ada total mention 3.850 dengan kategori mention negatif sebanyak 925 , positif 716 dan netral sebanyak 2,209. Tingginya perolehan percakapan ini menunjukkan bahwa warganet sangat antusias dalam pembahasan topik Pancasila. Hal itu sangat dipengaruhi oleh adanya konten yang berbasis Pancasila. Dengan demikian, konten memiliki peran yang sangat penting dalam upaya membumikan Pancasila di media sosial. Selain itu, dalam analisis ini akan dilacak perihal percakapan tersebut bisa dikatakan natural atau rekayasa. Oleh sebab itu, dalam percakapan ini dilakukan analisis bot terhadap akun-akun media sosial yang digunakan warganet dalam berinteraksi di media sosial dengan tema Pancasila. Analisis bot digunakan untuk melihat seberapa besar kemungkinan percakapan ini direkayasa oleh akun-akun bot (robot). 


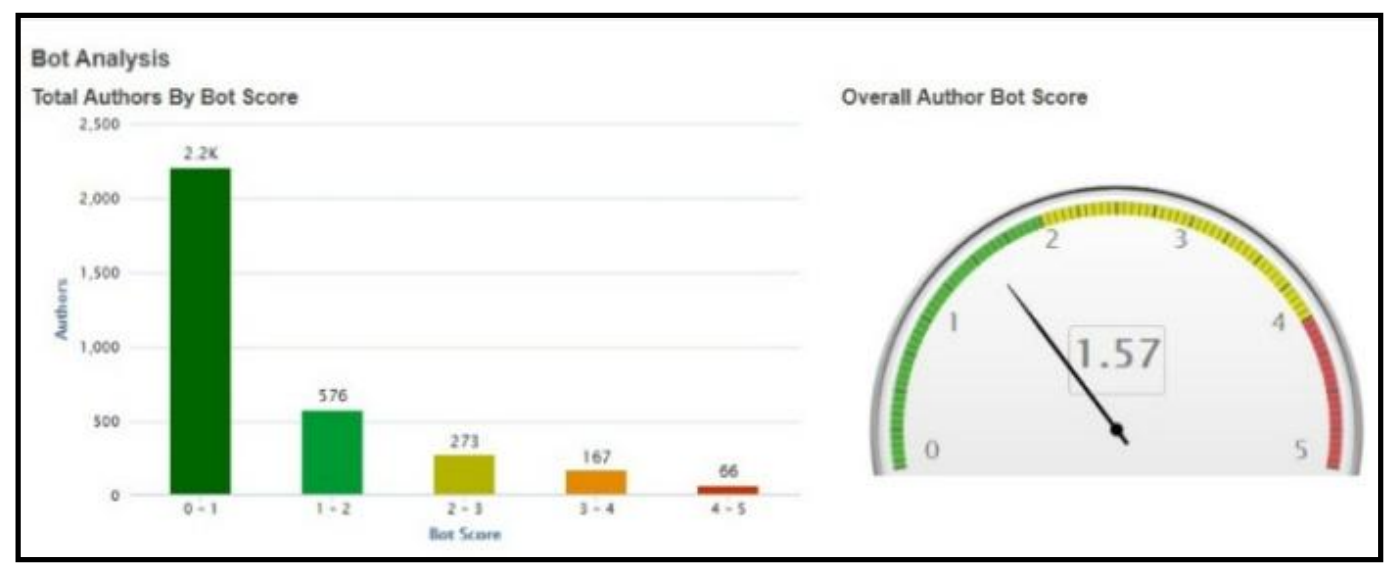

Gambar 3

Analisis akun bot dalam percakapan

Sumber Data : Drone Emprit Academic (2020)

Dalam analisis percakapan perihal generasi milenial dan Pancasila diketahui total keseluruhan percakapan sebanyak 7245 yang teridentifikasi. Dari jumlah keseluruhan postingan diketahui ada sebanyak 1,57 bot analisis. Dengan begitu angka sebesar 1,57 mengonfirmasi bahwa akun bot cukup kecil yang membuktikan percakapan yang terjadi di Twitter sangat natural. Dengan kata lain, percakapan ini terjadi bukan rekayasa dan benar-benar berasal dari para warganet yang sangat menyukai pembahasan perihal Pancasila. Sedangkan, untuk mayoritas pengguna media sosial yang membicarakan perihal Pancasila adalah akun-akun yang memiliki follower 101-500 sebesar 1.529 dengan persentase $42,43 \%$. Sehingga dapat disimpulkan bahwa generasi milenial sangat antusias bila diajak untuk membahas konten Pancasila. Pertanda ini membuktikan bahwa generasi milenial sangat menantikan konten-konten yang berbasis Pancasila. Dengan kata lain kesempatan ini yang harus terus digunakan dengan baik untuk bisa mengenalkan Pancasila lebih mendalam kepada generasi milenial. Salah satu langkah taktis adalah dengan mereproduksi konten berbasis Pancasila sebanyak mungkin untuk kemudian menjadi pandangan hidup para generasi milenial.

Dengan demikian, konten-konten tersebut yang akan mewujudkan warganet terutama generasi milenial menjadi nasionalis. Meski begitu untuk dapat menciptakan warganet nasionalis harus dimulai dari membangun komunitas digital bagi semua segmentasi komunitas warganet yang ada. Baik itu, komunitas blogger, disabilitas, perempuan, kesehatan ibu dan anak, hingga komunitas marginal di sekeliling kita. Pembelajarannya bisa dimulai dengan cara menggunakan media sosial yang bijak, membuat konten kreatif, memposting dan berkomentar dengan bernafaskan nilai-nilai Pancasila. Dengan demikian, keberadaan warganet yang memiliki nasionalis bisa ikut berkontribusi dalam membumikan Pancasila dalam ranah digital termasuk ikut mendorong partisipasi warganet secara aktif untuk ikut memproduksi konten berbasis Pancasila.

\section{Simpulan}

Generasi milenial merupakan mayoritas pengguna media sosial yang biasanya digunakan untuk berkomunikasi serta dijadikan referensi hingga pegangan hidup. Hal itu tampak mulai dari gaya berkomunikasi, berteman, bertukar informasi hingga mengikuti budaya yang paling populer yang beredar di media sosial. Bahkan untuk gaya berbicara dengan sapaan milenial banyak terlahir dari ranah media sosial. Inilah yang kemudian membuat media sosial sangat mempengaruhi semua sendi kehidupan para generasi milenial. Dengan begitu, informasi yang paling kuat beredar di media sosial, otomatis akan menjadi informasi yang paling utama didengar sehingga kemungkinan besar bisa menjadi cara pandang para milenial dalam setiap aktivitas keseharian. Dengan begitu, media sosial sangat berperan penting dalam upaya mengubah cara pandang para generasi milenial. Cara pandang 
ini bisa kearah negatif maupun positif tergantung dari seberapa besar para generasi milenial ini menerima suatu informasi.

Dalam hal ini diketahui bahwa generasi milenial sangat antusias dengan nilai-nilai Pancasila yang terdapat dalam konten-konten berbasis Pancasila. Meski pada kenyataannya di media sosial sangat jarang ditemui konten berbasis Pancasila. Dikarenakan banyak beredar konten-konten yang tidak mencerminkan nilai-nilai Pancasila hingga konten yang anti dengan ideologi Pancasila. Selain itu untuk mengenalkan Pancasila kepada generasi milenial tidak hanya menawarkan konten berbasis Pancasila semata, akan tetapi dibutuhkan peran aktor warganet. Aktor inilah yang ikut menentukan suatu pesan atau konten Pancasila dapat tersebar luas kepada generasi milenial atau sebaliknya. Dengan kata lain, aktor warganet tersebut akan sangat menentukan keberhasilan membumikan Pancasila di media sosial. Dengan demikian penelitian ini menyimpulkan bahwa pandangan generasi milenial terhadap konten Pancasila sangat antusias, yang dibuktikan oleh tingginya interaksi yang terjadi dalam percakapan terhadap konten berbasis Pancasila. Bahkan, mayoritas generasi milenial memberikan apresiasi yang tinggi terhadap konten berbasis Pancasila melalui penanda di media sosial seperti retweet, like hingga ikut berkomentar positif. Meski demikian, untuk dapat membumikan Pancasila di media sosial, tetap dibutuhkan sinergisitas dari simpul masyarakat untuk ikut memproduksi berbagai konten berbasis Pancasila. Dengan konten Pancasila tersebut, tentulah pandangan generasi milenial terhadap Pancasila akan semakin menguat, sehingga kemudian akan menjadikan nilai-nilai Pancasila sebagai pegangan hidup bersama.

\section{Referensi}

Adji, W. S., Bashith, A., Nasith, A., \& Amin, S. (2019). Identification of Social Symptoms Using the Drone Emprit Academic as a Support for Statistical Literacy. Abjadia: International Journal of Education, 04(02), 97-106. https://doi.org/10.18860/abj.v4i2.8412

Arianto, B. (2015a). Kampanye Kreatif dalam Kontestasi Presidensial 2014. Jurnal Ilmu Sosial dan Ilmu Politik UGM, 19 (1), 16-39.

Arianto, B. (2020b). Salah Kaprah Ihwal Buzzer: Analisis Percakapan Warganet di Media Sosial. Jurnal Ilmiah Ilmu Pemerintahan (JIIP) Undip, 5 (1), 1-20.

Arianto, B. (2020c). Peran Buzzer Media Sosial dalam Memperkuat Ekosistem Pemasaran Digital. Jurnal Optimum UAD, 10(1), 51-65.

Arianto, B. (2020d). Pemanfaatan Aplikasi Drone Emprit Academic dalam Menganalisis Opini Publik di Media Sosial. Journal of Social Politics and Governance, 2(2), 177-191.

Asmaroini, A. P. (2016). Implementasi Nilai-Nilai Pancasila Bagi Siswa Di Era Globalisasi. Citizenship Jurnal Pancasila dan Kewarganegaraan, 4(2), 440-450.

Bowman, B. S., \& Willis, C. (2003). We Media: How audiences are shaping the future of news and information. California: The Media Center at the American Press Institute.

Damanhuri, et al., (2016). Implementasi Nilai-Nilai Pancasila Sebagai Upaya Pembangunan Karakter Bangsa. Untirta Civic Education Journal, 1(2).

Effendi, F. P., \& Dewi, D. A. (2021). Generasi Milenial Berpancasila di Media Sosial. Journal Civics \& Social Studies, 5(1), 116-124.

Emillia, E. (2020). Penguatan Sila Ketiga Pancasila Sebagai Solusi Untuk Menghadapi Penyebarluasan Content Berunsur SARA Di Media Sosial. Jurnal Pendidikan Kewarganegaraan, 7(1), 1-10.

Handitya, B. (2019). Menyemai Nilai Pancasila Pada Generasi Muda Cendekia. ADIL Indonesia Journal, 1(2).

Fahmi. I. (2019). Drone Emprit Academic: Software for Social Media Monitoring and Analytics. Available at http://uii.ac.id

Katadata.com. (2017). Polisi Bongkar Sindikat Saracen Penyebar Kebencian di Media Sosial. Diakses 
31 Desember 2019.. www.Katadata.Com. https://katadata.co.id/berita/2017/08/23/polisibongkar-sindikat-saracen-penyebar-kebencian-di-media-sosial

Kominfo.go.id. (2016). Mengenal Generasi Milenial. Diakses 30 Desember 2019. https://www.kominfo.go.id/content/detail/8566/mengenal-generasimillennial/0/sorotan_media

Loader, B. D., \& Mercea, D. (2011). Networking democracy? Social media innovations and participatory politics. Information, Communication \& Society, 14(6), 757-769.

Muharam, R.S., \& Prasetyo, D. (2021). Pemanfaatan Media Youtube untuk Mendukung E-Learning Pendidikan Kewarganegaraan di Perguruan tinggi. Jurnal Citizenship: Media Publikasi Pendidikan Pancasila dan Kewarganegaraan, 4 (1), 1-12.

Pratama, A. Y., \& Noventari, W. (2018). Revitalisasi Nilai-nilai Pancasila: Kajian Historis Dari Demokrasi Terpimpin Hingga Era Millenial. Seminar Nasional PKn UNNES (Vol. 2, No. 1, pp. $1-15)$.

Safitri, A., \& Dewi, D. A. (2021). Implementasi Nilai-Nilai Pancasila sebagai Pedoman Generasi Milenial dalam Bersikap di Media Sosial. EduPsyCouns: Journal of Education, Psychology and Counseling, 3(1), 78-87.

Susanto, H. (2018). Pendidikan karakter di Era Milenial. Seminar Nasional Pendidikan dan Kewarganegaan IV, 15-21).

Suwandi, N. P., \& Dewi, D. A. (2021). Implementasi Pancasila Untuk Membangun Karakter Generasi Muda. Antropocene: Jurnal Penelitian Ilmu Humaniora, 1(10), 1-6.

Triastuti, R. (2019). Teachers and technology: The perspective of digital citizenship. Jurnal Civics: Media Kajian Kewarganegaraan, 16(1), 22-28.

Wulandari, A. D., \& Dewi, D. A. (2021). Urgensi Membumikan Pancasila Bagi Karakter Penerus Bangsa di Era Globalisasi. Jurnal Pendidikan Tambusai, 5(1), 926-930. 